\title{
Research on the Mechanical Properties of New Double-Row Pile Supporting Structure Based on an In Situ Study
}

\author{
Yijun Zhou $\mathbb{D}^{1},{ }^{1}$ Kuiming Liu $\mathbb{D}^{2},{ }^{2}$ and Fengnian Wang $\mathbb{D}^{2}$ \\ ${ }^{1}$ College of Architecture and Engineering, North China University of Science and Technology, Tangshan 063210, China \\ ${ }^{2}$ State Key Laboratory for Geomechanics \& Deep Underground Engineering, Beijing 100083, China \\ Correspondence should be addressed to Fengnian Wang; wangfn_bj@163.com
}

Received 4 May 2021; Accepted 22 May 2021; Published 1 June 2021

Academic Editor: Yun Lin

Copyright (c) 2021 Yijun Zhou et al. This is an open access article distributed under the Creative Commons Attribution License, which permits unrestricted use, distribution, and reproduction in any medium, provided the original work is properly cited.

According to the force characteristics of the double-row pile supporting structure, two new types of double-row piles are developed: the prestressed strong-constrained double-row piles and the recycling assembled double-row piles. A comparative field test was conducted on the support effects of the two new double-row piles and conventional double-row piles. The test site is located in a deep foundation pit of the Beijing Daxing International Airport Project. The feasibility and reliability of the two new support structures are verified. Field monitoring included section strain and bending moment of the pile body, horizontal displacement of the pile body, and vertical and horizontal displacement of the pile top. The research shows that because of the prestressed anchorage cables in the rear row piles, the prestressed strong-constrained support structure can provide better tensile performance from the rear piles, and the deformation and displacement are minimal. The recycling assembled double-row piles have similar deformation and displacement to the conventional piles. Through the connection of the steel members, the construction time can be effectively shortened. After the backfill of the foundation pit, the steel members can be recycled and the cost can be reduced.

\section{Introduction}

Currently, double-row pile support structures are widely used in slope engineering, hydraulic engineering, road engineering, and other fields. This type of support structure mainly consists of front row piles, rear row piles, crown top beams, and coupling beams $[1,2]$. It can also be regarded as the case where the total number of piles does not change, and a single row of piles is transferred to the rear row to form parallel front and rear rows. The spatial structure system is formed by connecting several beams to the tops of the piles [3-6], as shown in Figure 1.

Many scholars have studied conventional double-row pile support structures based on the unique structural form and stress variation characteristics. Based on the classic earth pressure theory in China, the most representative one is the volume-ratio coefficient method proposed by $\mathrm{He}$ et al. [7]. Nie et al. [8] used a combination of model tests, numerical simulations, and field tests to systematically study the distribution of earth pressure, displacement of front and rear row piles, and bending moments of the front and rear rows of double-row piles in a foundation pit excavation. Nie et al. summed up the laws of these observations and proposed a theoretical calculation method based on the spatial effects. Based on previous research and the Winkler foundation beam theory, Zheng et al. [9] proposed a new plane element finite element model considering pile-soil interaction. Wang and Zhao [10] started with the multilayer soil arch effect of double-row piles, analyzed the mechanical properties of two types of soil arches (end-bearing arches and friction arches) at the arch foot, and derived two types of soil arches. The ultimate load-carrying capacity was then studied by analyzing the problems of landslide thrust distribution in front row piles, soil resistance in front of the piles, and spacing between the front and rear row piles.

All of the above studies are based on the traditional double-row pile support structure, and there is less research on the optimization and improvement of the traditional 


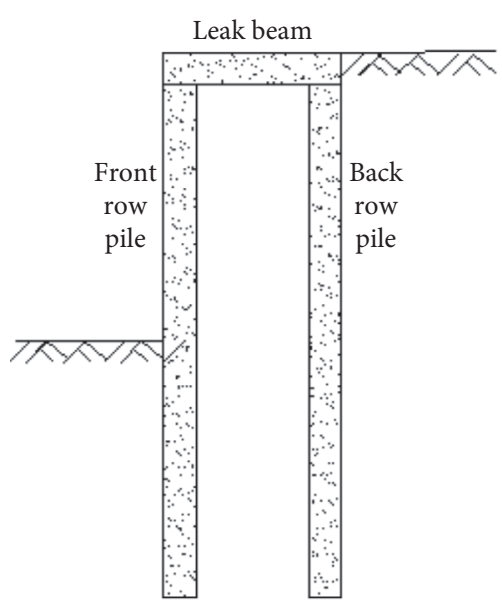

FIgURE 1: Schematic diagram of traditional double-row pile support structure.

support structure [11-16]. It is also short of comparison of mechanical properties for supporting structures and some in situ studying [17-21]. Double-row pile supporting structure is used in mining engineering and geotechnical engineering [22-25]. At the same time, the traditional double-row pile support structure also has its drawbacks. First, because its structural form is more complex than a single row pile, the construction period is longer. Second, because it consists of two rows of piles, the project cost is much higher than that of single row piles. Therefore, based on the deficiencies of the above traditional double-row piles, according to the force characteristics of the double-row pile support structure, two new types of double-row pile support structures were developed in this study and field-tested: the prestressed strongconstrained double-row piles and the recycling assembled double-row piles. A comparative test was conducted with traditional double-row piles to verify the feasibility and reliability of the new support structures.

\section{Project Overview}

2.1. Test Site Overview. The test site is located in a deep foundation pit of the Beijing Daxing International Airport Project, located in Yufa town and Lixian town of Daxing District in Beijing and Guangyang District of Langfang city in Hebei province, as shown in Figure 2. The specific test area is south from the terminal building, north to the north border of the remote parking lot (Paradise Henan Coast after manual diversion), west about $250 \mathrm{~m}$ to the main entrance road viaduct $\mathrm{A} 2$, and east to the east side of South Central Axis Road about $450 \mathrm{~m}$. The overall layout is one horizontal and four vertical.

2.2. Engineering Geological Conditions. The field test site is shown in Figure 3. Based on the comprehensive analysis of onsite conditions, in situ testing, and the results of the indoor geotechnical tests, the strata within the depth of the survey were divided into three categories: artificial accumulation, recent sedimentary, and quaternary sedimentary. The strata are divided into five main layers and their

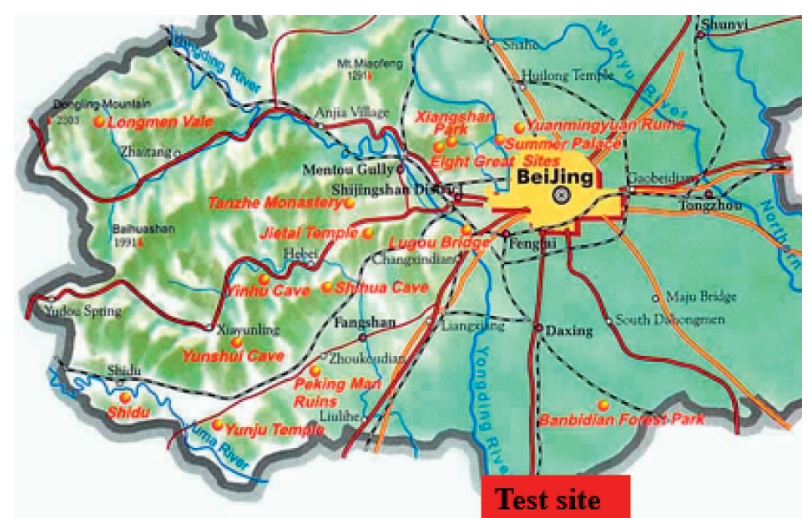

FIgURE 2: Location of test sites.

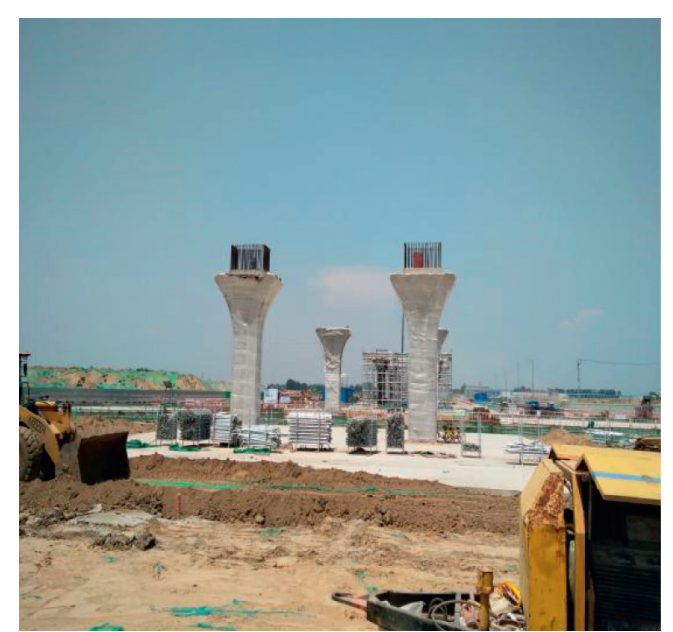

FIgURe 3: Test site.

sublayers according to their lithology, physical and mechanical properties, and engineering characteristics. The groundwater level is about 2 meters.

\subsubsection{Artificial Accumulation Layer ( $1^{\text {st }}$ Major Layer).} The surface layer of the test field is generally covered with an artificial accumulation layer with a thickness of $0.40 \sim 1.80 \mathrm{~m}$, which consists of a clayey silt soil layer, sandy silty soil fill (1) layer, and slag soil (1) layer. The local distribution may be thicker, as influenced by human transformation.

2.2.2. Recent Sedimentary Layers ( $2^{\text {nd }}$ and $3^{r d}$ Major Layers). Under the artificial accumulation layer, the recent sedimentary layers consist of the newly deposited sandy silt and clayey silt (2) layers, silty sand and fine sand (2) 1 layers, organic clay, organic heavy silty clay (2) 2 layers, silty clay and clayey silt (2) 3 layers, sandy silt and clayey silt (3) layers, organic clay and organic heavy silty clay (3) layers, fine sand and silty sand (3) 2 layers, and silty clay and clayey silt (3) 3 layers.

2.2.3. Quaternary Sedimentary Layers ( $4^{\text {th }}$ and $5^{\text {th }}$ Major Layers). Under the new sedimentary layer, the quaternary sediments are silty clay and clayey silt (4) layers, silty clay and 
sandy silt (4) layers, fine sand and silty sand (4) layers, heavy silty clay and clay (4) 3 layers, and fine sand and medium sand (5) layers.

\section{New Support Structures}

The prestressed strong-constrained type support is created by adding a prestressed anchor cable along the pile at the top of the rear row of piles, and the anchors are tied to the inside of the reinforcement cage. After the reinforcement cage is driven into the pile holes and the concrete of the pile has reached the strength requirements, the anchor cable is tensioned. Due to the increase in the tensile strength of the rear row of piles, the length of the front row piles can be appropriately shortened, as shown in Figure 4(a). A single prestressed anchor cable has a nominal value of $15.2 \mathrm{~mm}$, and three of them are used, and the prestress value is $100 \mathrm{kN}$.

The recycling assembled type support uses detachable steel components instead of the traditional crown beams and coupling beams, while the rear row piles use steel pipe piles instead of traditional bored piles, as shown in Figure 4(b).

The numbers in Figure 4(a) represent the following: (1) front row pile, (2) crown beam of front row pile, (3) coupling beam, (4) soil between piles, (5) rear row pile, (6) crown beam of rear row pile, (7) anchor pad, (8) steel reinforcement cage, (9) prestressed anchorage cable, (10) free section of anchor cable, and (11) anchoring section of anchor cable.

The numbers in Figure 4(b) represent the following: (1) front row pile (bored concrete pile), (2) crown beam of front row pile, (3) rear row pile (steel pipe pile), (4) pile cap, (5) tie sleeve, (6) tie rod, (7) locking joint, (8) steel reinforcement cage, (9) paint layer, (10) pin shaft, and (11) keyhole.

In order to fully compare the mechanical properties of the two new types of double-row pile retaining structures and the conventional ones, the three types of piles were all cast with C30 concrete. The compressive strength of concrete was $14.3 \mathrm{~N} / \mathrm{mm}^{2}$, and the elastic modulus was $3 \times 104 \mathrm{~N} /$ $\mathrm{mm}^{2}$. The longitudinal reinforcement of the pile is $14 \mathrm{~B} 20$ HRB400 steel bars, and the stirrups are HRB400, $\phi 12 @ 200$, and $\phi 16 @ 2000$. The geometric design parameters of the three types of piles are given in Table 1.

\section{Field Monitoring}

4.1. Field Monitoring Scheme Design. The purpose of this field test is to determine the mechanical properties of the new double-row pile retaining structures in the excavation process of the foundation pit, explore the displacement and deformation behavior of the new pile types, and comprehensively evaluate the working performance of the new pile types in the field test.

In order to reveal the law of displacement and deformation of the new pile type, the changes of the conventional double-row pile supporting structures after the force deformation are compared. The test focuses on the horizontal and vertical displacement of the pile top and horizontal displacement of the pile body. The pile body deformation was monitored, as given in Table 2. Based on the abovementioned monitoring items, reliability, accuracy, and convenience were taken as criteria for the selection of monitoring instruments.

The field monitoring instruments are shown in Figure 5.

4.2. Field Monitoring Scheme Implementation. The displacement measurement point plan view of the pile tops is shown in Figure 6, and the reflective sheet site layout is shown in Figure 7.

The plan view of the inclinometer pipe is shown in Figure 8, and the site embedment plan is shown in Figure 9.

The site construction process consisted of the following steps and is shown in Figure 10.

(1) Behind the pile, a trench with a depth of $1 \mathrm{~m}$, width of $2 \mathrm{~m}$, and length of about $25 \mathrm{~m}$ was excavated for laying the steel strands. In order to minimize the disturbance of the overlying soil on the steel strands, aluminum-plastic tubes and iron tubes are sheathed outside the steel strands.

(2) At the end of the trench away from the foundation pit, a $1.5 \mathrm{~m}$ long steel bar was drilled into the bottom of the pit to firmly connect the steel strand to the exposed bar head as a fixed point

(3) The other end of the strand was extended to the top of the crown girder and connected to the cable-type displacement meters of the piles at the top and the rear of each pile, respectively

(4) The connections of the whole system were checked, the initial data values were collected, and the groove was carefully filled.

The strain of pile body was monitored by a vibrating wire embedded strain gauge. The strain gauges were bound to the main reinforcement of the steel reinforcement cage symmetrically, and the vertical spacing was $200 \mathrm{~mm}$ from top to bottom. The elevation view of the measuring point layout is shown in Figure 11, and the gauge burial is shown in Figure 12.

When the installation of each monitoring point was complete and the commissioning was correct, the initial values were collected and the excavation of the foundation pit was carried out. The pit was designed for a depth of $8 \mathrm{~m}$, excavated in four steps at a rate of $2 \mathrm{~m}$ for each step, and the concrete was sprayed on the wall of the foundation pit after each excavation to prevent runoff between piles. After each excavation step, data acquisition was performed for each monitoring aspect three times/day (morning, afternoon, and evening) to capture the time of the initial changes in the data during excavation. The monitoring continued until the fifth day when the pit excavation was completed. The excavation process of the foundation pit is shown in Figure 13.

\section{Results and Discussion}

\subsection{Displacement Analysis of Pile Top}

5.1.1. Vertical Displacement. As shown in Figure 14, positive values on the vertical axis indicate that the top of the pile is floating and the negative values indicate that the pile top is 


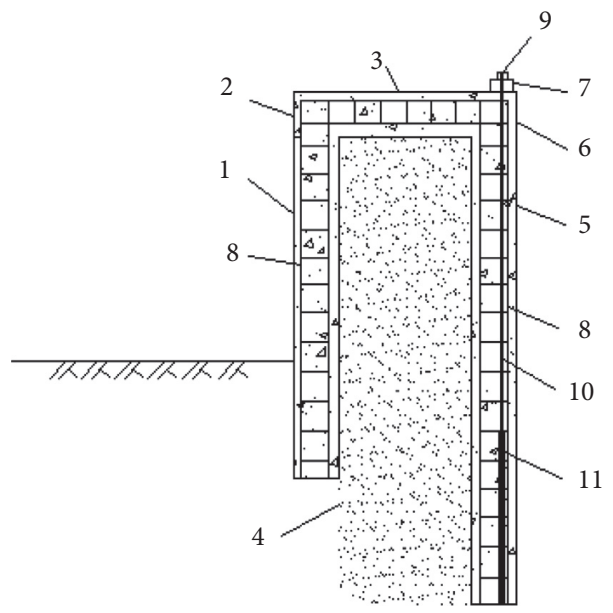

(a)

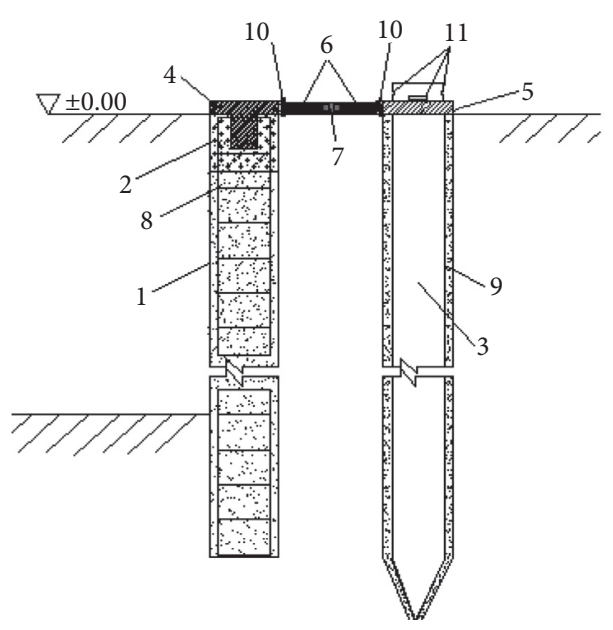

(b)

FIgURe 4: Elevation view of new double-row piles. (a) Prestressed strong-constrained double-row piles. (b) Recycling assembled double-row piles.

Table 1: Geometric design parameters of test piles.

\begin{tabular}{|c|c|c|c|c|c|c|}
\hline Test pile type & $\begin{array}{l}\text { Crown beam } \\
\text { size }(\mathrm{m})\end{array}$ & $\begin{array}{l}\text { Length of front and rear } \\
\text { row pile }(\mathrm{m})\end{array}$ & $\begin{array}{l}\text { Pile diameter } \\
(\mathrm{m})\end{array}$ & $\begin{array}{l}\text { Row spacing } \\
(\mathrm{m})\end{array}$ & $\begin{array}{l}\text { Pile spacing } \\
(\mathrm{m})\end{array}$ & $\begin{array}{l}\text { Depth of foundation } \\
\text { pit }(\mathrm{m})\end{array}$ \\
\hline Conventional & $0.8 \times 0.8$ & $12.5 / 12.5$ & 0.8 & & & \\
\hline $\begin{array}{l}\text { Prestressed strong- } \\
\text { constrained }\end{array}$ & $0.8 \times 0.8$ & $10.0 / 12.5$ & 0.8 & 2.4 & 2.0 & 8 \\
\hline Recycling assembled & - & $12.5 / 12.5$ & $0.8 / 0.6$ & & & \\
\hline
\end{tabular}

TABle 2: Test procedure.

\begin{tabular}{|c|c|c|c|}
\hline Property & Monitoring position & Monitoring quantity & Instrument \\
\hline Pile strain & $\begin{array}{l}\text { Conventional front and rear } \\
\text { row pile } \\
\text { Prestressed strong- } \\
\text { constrained front and rear } \\
\text { row pile } \\
\text { Recycling assembled front } \\
\text { row pile }\end{array}$ & $\begin{array}{l}\text { Conventional pile strain gauge: five } \\
\text { groups + one branch } \\
\text { Prestressed strong-constrained pile } \\
\text { strain gauge: four groups + two } \\
\text { branches } \\
\text { Recycling assembled pile strain } \\
\text { gauge: five groups }\end{array}$ & $\begin{array}{l}\text { Vibrating string embedded strain } \\
\text { gauge (BGD-4200) }\end{array}$ \\
\hline $\begin{array}{l}\text { Horizontal displacement of } \\
\text { pile body }\end{array}$ & $\begin{array}{l}\text { Conventional front row pile } \\
\text { Prestressed strong- } \\
\text { constrained front row pile } \\
\text { Recycling assembled front } \\
\text { row pile }\end{array}$ & $\begin{array}{l}\text { Three types of front row pile for a } \\
\text { total of six }\end{array}$ & Clinometer \\
\hline $\begin{array}{l}\text { Horizontal displacement and } \\
\text { vertical displacement of pile } \\
\text { top }\end{array}$ & $\begin{array}{l}\text { Conventional front and rear } \\
\text { row pile } \\
\text { Prestressed strong- } \\
\text { constrained front and rear } \\
\text { row pile } \\
\text { Recycling assembled front } \\
\text { and rear row pile }\end{array}$ & $\begin{array}{l}\text { One of three types of front and rear } \\
\text { piles, a total of } 12 \text { measuring points }\end{array}$ & $\begin{array}{l}\text { Remote displacement automatic } \\
\text { monitoring system, electronic total } \\
\text { station }\end{array}$ \\
\hline
\end{tabular}

sinking. Before the excavation in the third step of the three types of piles, the vertical displacement of the piles at the front and rear rows was minimal. When the excavation reached the third step, the vertical displacement of the pile top appears to be floating. After the fourth excavation was completed, the vertical displacement of the pile top is basically stable, about $1 \mathrm{~mm}$. The main purpose of the analysis is that with the excavation of the foundation pit, the unloading effect of the soil in front of the pile is gradually obvious, and the soil at the bottom of the pit has a certain rebound, which causes the floating phenomenon of the top and bottom of the piles. This conclusion is also consistent with the indoor physical simulation test pile top displacement changes. 


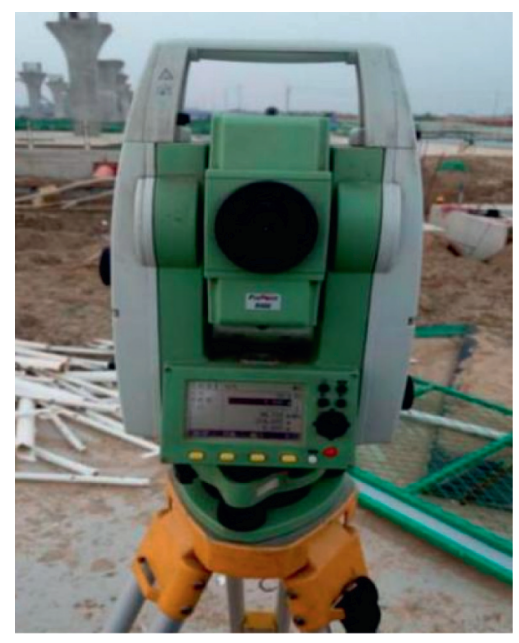

(a)

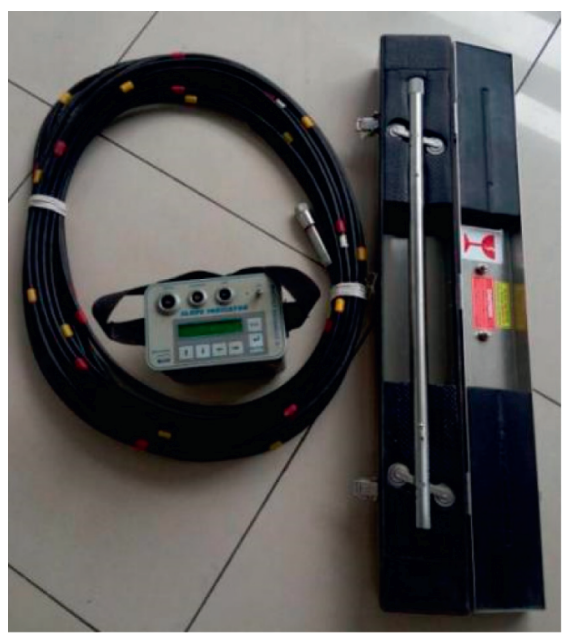

(b)

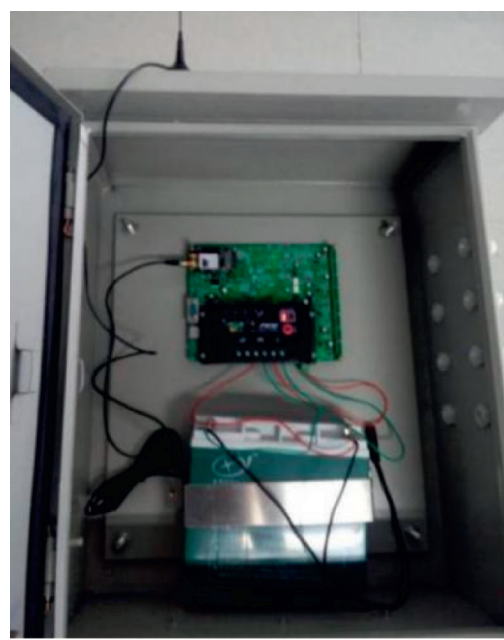

(c)

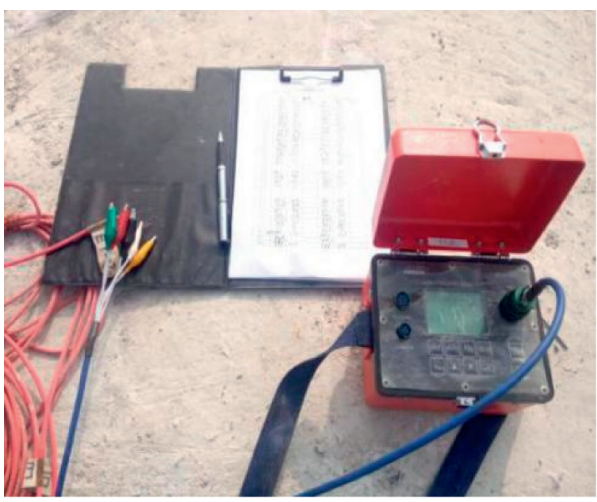

(d)

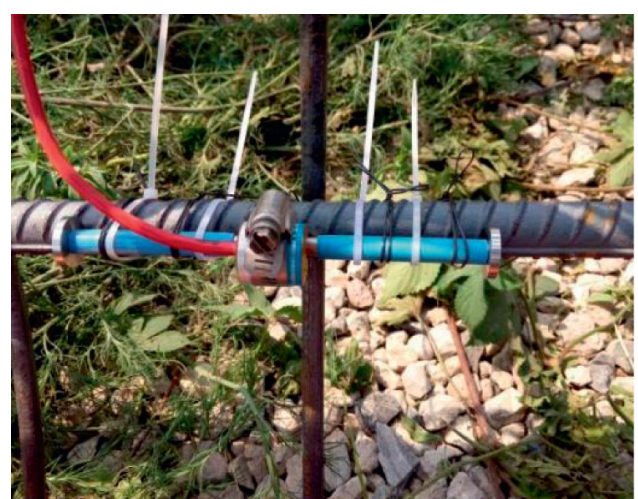

(e)

FIGURE 5: Field test monitoring instruments. (a) Electronic total station. (b) Clinometer. (c) Remote automatic displacement monitoring system. (d) Strain collector BGK408. (e) Strain gauge BGD-4200.

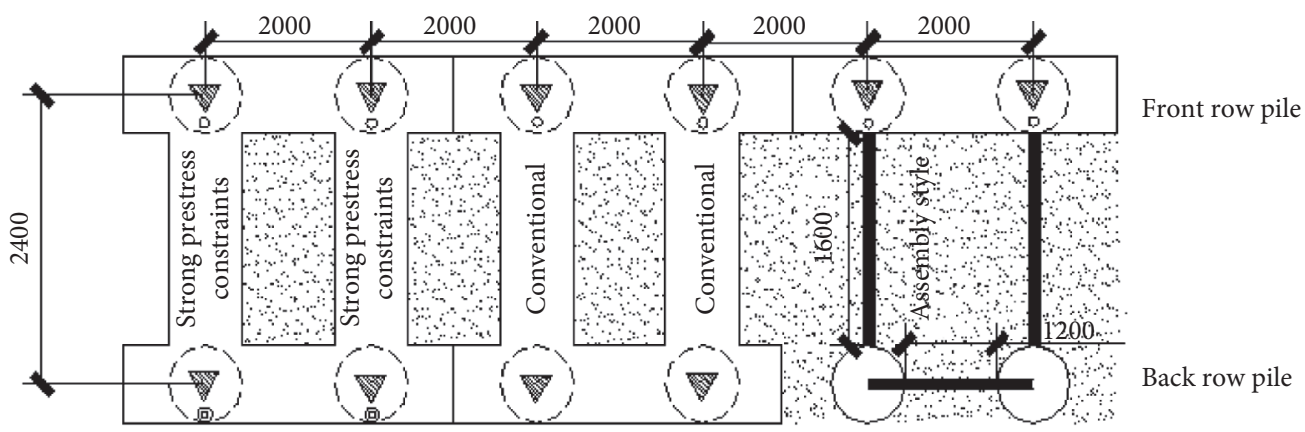

Vertical displacement monitoring point

Horizontal vertical displacement monitoring point

Figure 6: Pile top displacement measurement point plan view.

Due to the summer flood season, after the excavation of the foundation pit, heavy rainfall occurred in the test area for several consecutive days, resulting in sinking of the vertical displacements of the front and rear pile tops, especially for the recycling assembled double-row piles. The sinking of the front row piles was $-2 \mathrm{~mm}$, and the sinking of the rear row piles was $-3 \mathrm{~mm}$. The main reason for the analysis is that the strata within the site are mainly 


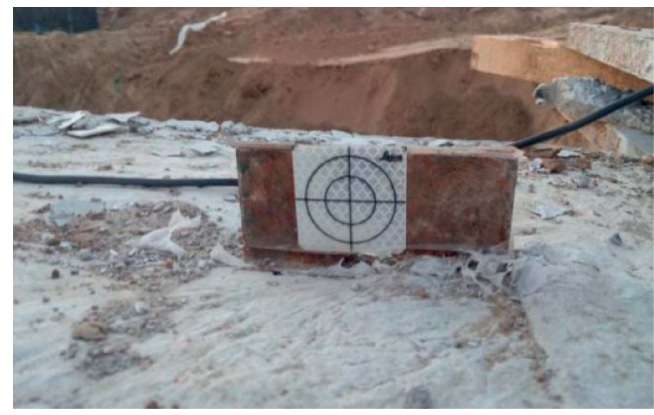

FIgURE 7: Reflective sheet in pile top.

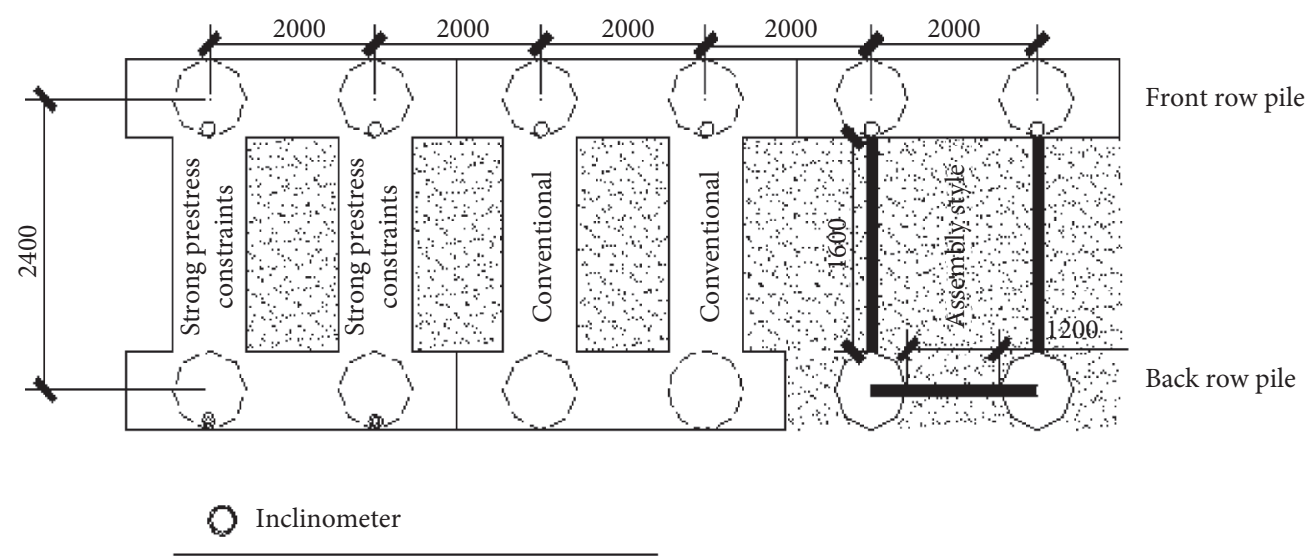

FIgURE 8: Inclinometer plan.

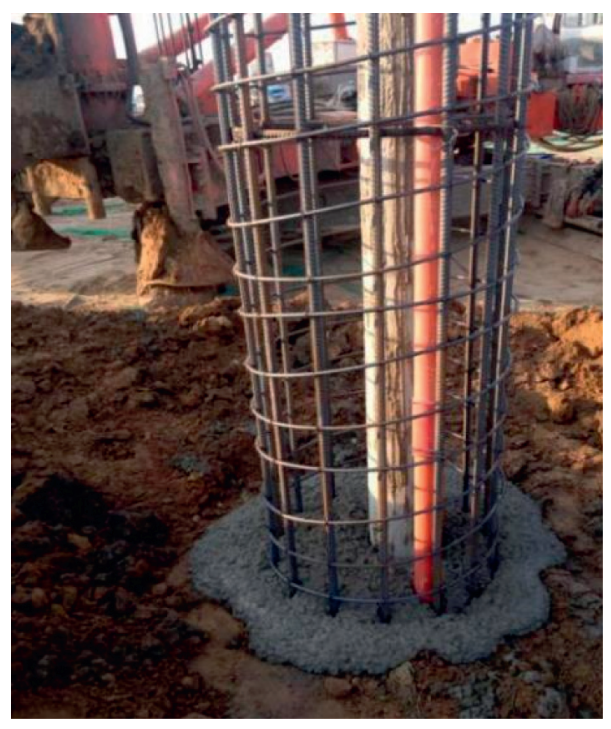

(a)

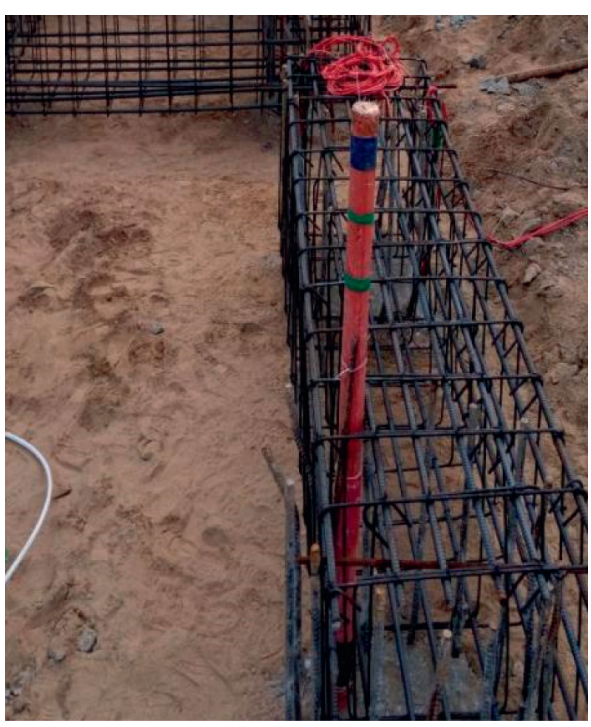

(b)

FIGURE 9: Inclinometer pipe site layout.

composed of thick clayey soil, silty soil, and sand soil, and the soil structure is relatively loose, so the engineering properties are poor. Under strong rain, the bottom of the pit is weakened with water and soil. Therefore, the pile body sinks under the tow of the soil around the pile, and since the hollow steel pipe pile is used for the recycling assembled rear pile, the weight of the pile is smaller, and the towing effect is more obvious. 

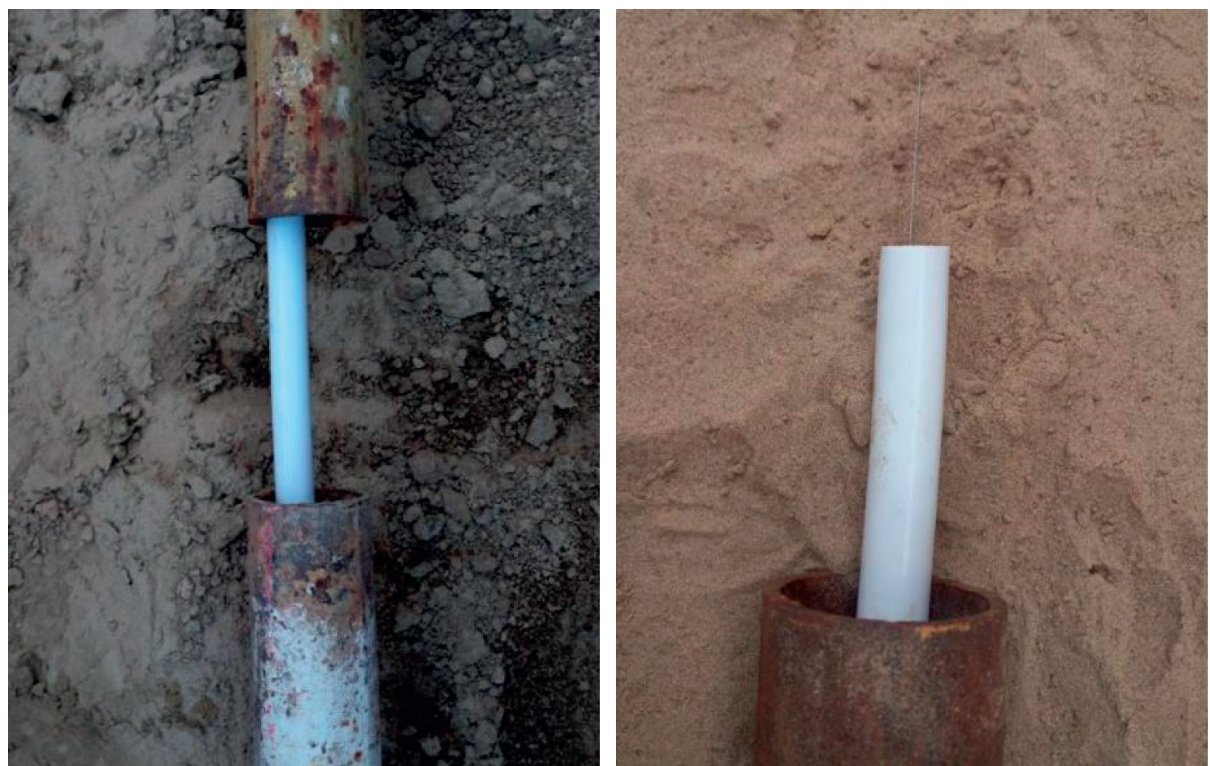

(a)
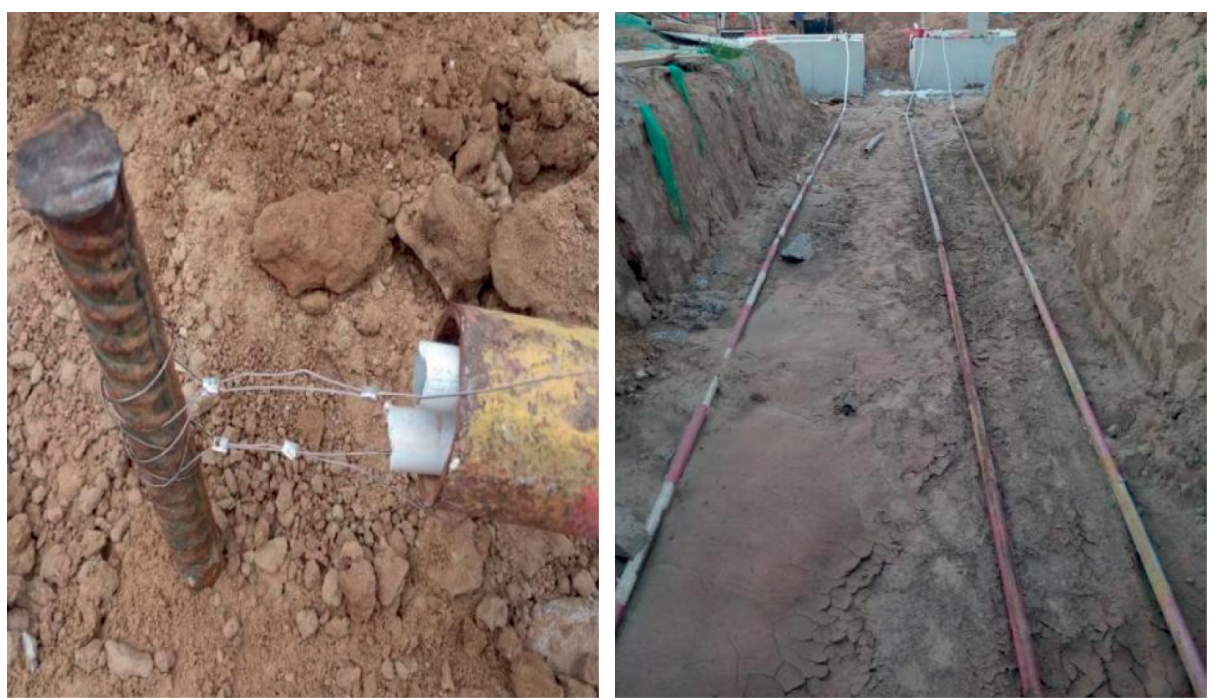

(b)
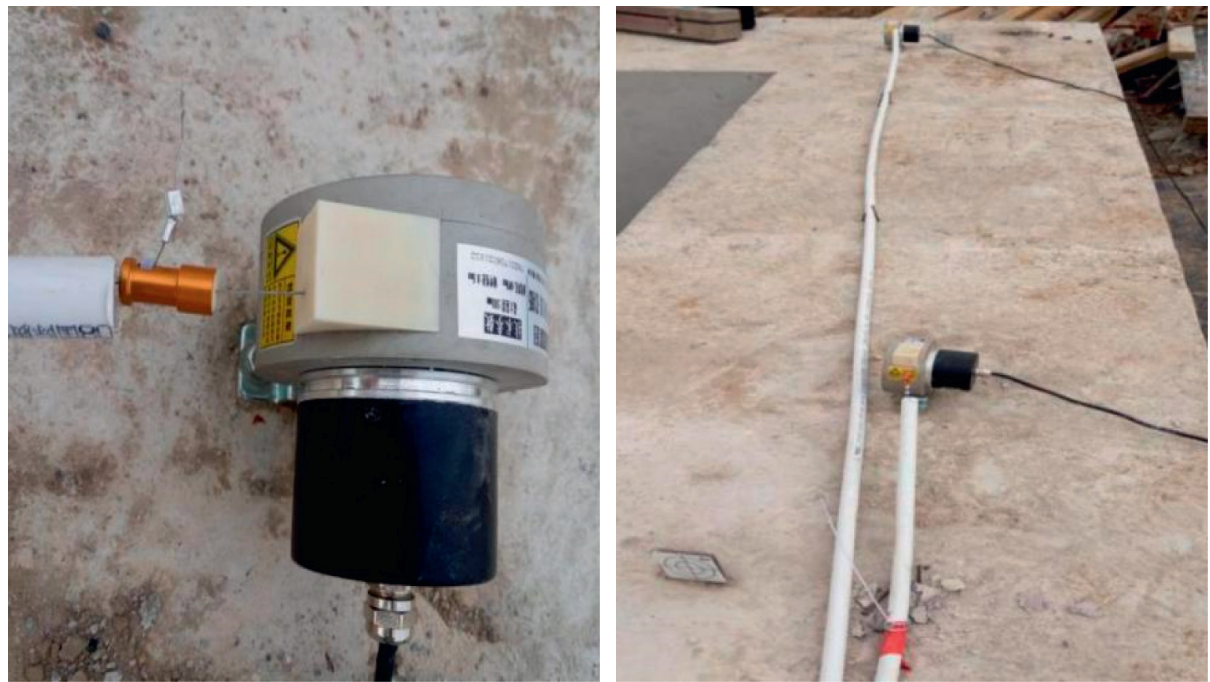

(c)

FIGURE 10: Connection diagram of the remote displacement automatic monitoring system. (a) Relative position of the aluminum-plastic tube, iron pipe, and steel strand. (b) Fixed point connection behind the pile. (c) Connection of guyed displacement gauge on the pile top. 


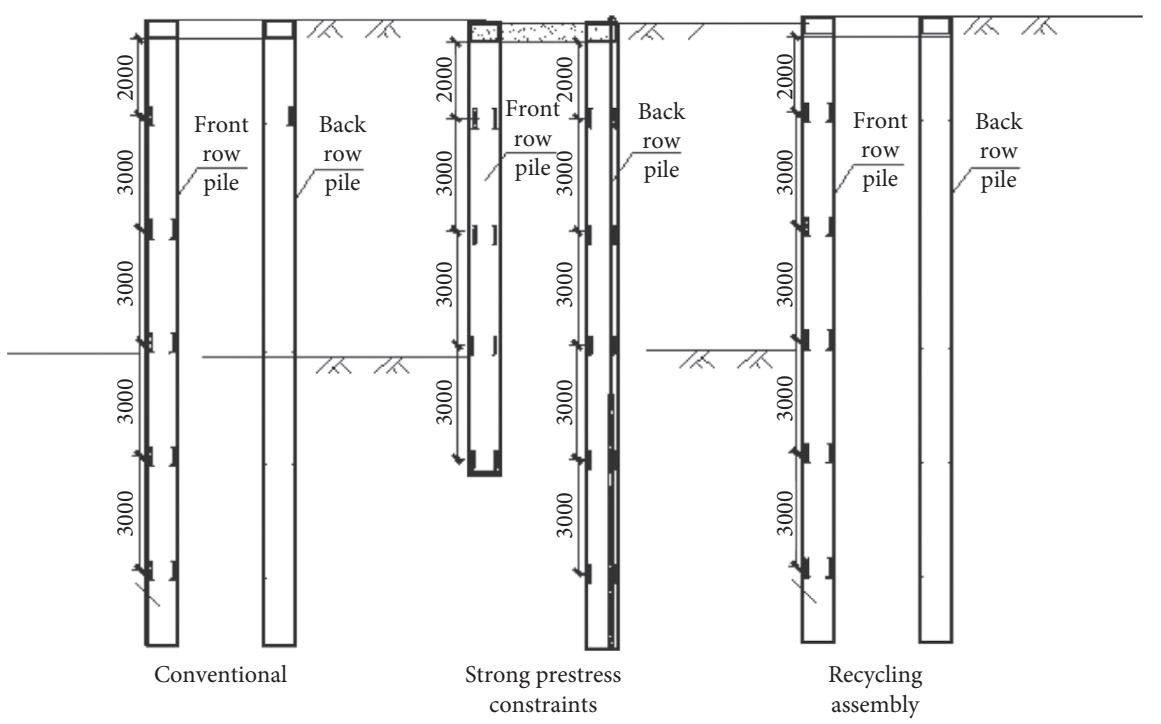

FIgURE 11: Pile strain measuring point layout elevation.

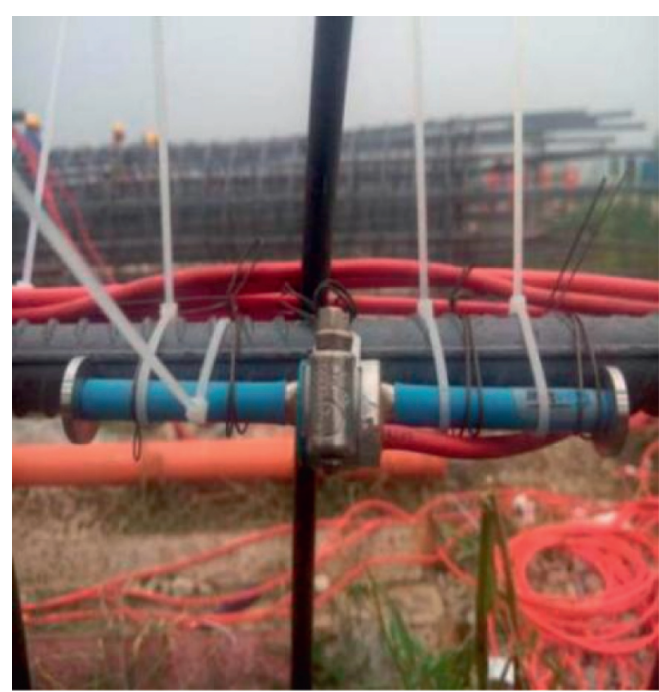

(a)

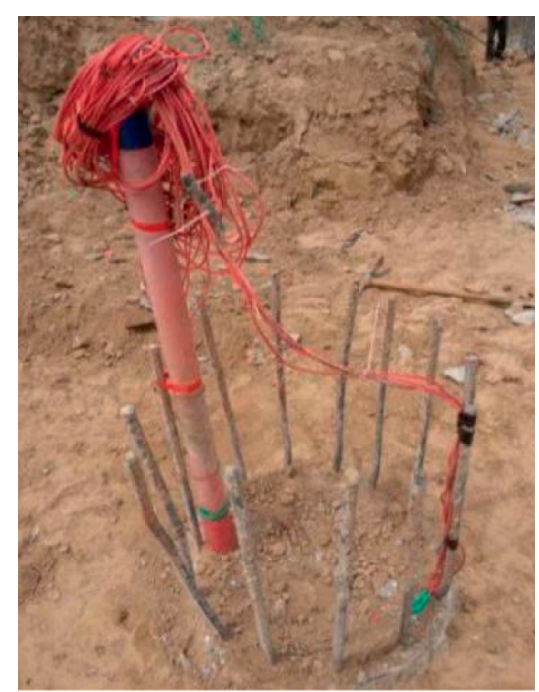

(b)

Figure 12: Binding and burial of strain gauges.

5.1.2. Horizontal Displacement. Positive values on the vertical axis in Figure 15 indicate displacements in the direction of the foundation pit and negative values indicate displacements in the direction away from the foundation pit. As shown, the horizontal displacement variation trends of the conventional and recycling assembled pile top are basically the same. However, for the prestressed strong-constrained pile, due to the effect of the prestressed anchor cable, the horizontal displacement of pile top has a negative value in the early stage of monitoring, which means the displacement is far away from the foundation pit. With the continuous excavation of the foundation pit, the horizontal displacement of the prestressed strong-constrained piles at the front and rear piles is gradually displaced toward the direction of the foundation pit. When the excavation of the foundation pits occurred, the horizontal displacements of the piles at the front and rear piles all abruptly changed, which indicates that the excavation of foundation pits is the main influencing factor of the horizontal displacement of the pile tops. Moreover, as the excavation depth of the foundation pit increases, the displacement increases gradually and the displacement at the end of monitoring reaches a maximum value. Among them, the horizontal displacements of the prestressed strong-constrained front row pile, the recycling assembled type front row pile, and the conventional front row pile top were $2.52 \mathrm{~mm}, 5.78 \mathrm{~mm}$, and $5.56 \mathrm{~mm}$, respectively. The corresponding horizontal displacements of the rear row of piles are $1.72 \mathrm{~mm}, 4.52 \mathrm{~mm}$, and $4.11 \mathrm{~mm}$, respectively. The horizontal displacements of the piles at the front row of each pile are larger than those of the rear piles, which is consistent with the changing trend of the previous numerical simulation results. 


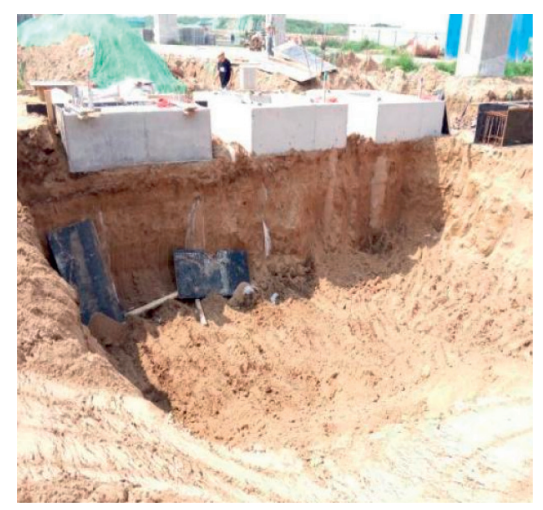

(a)

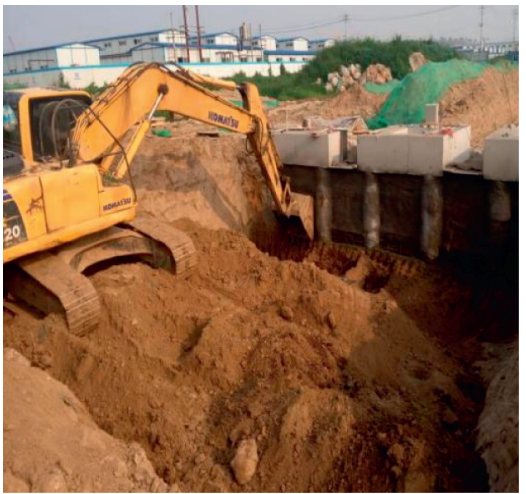

(d)

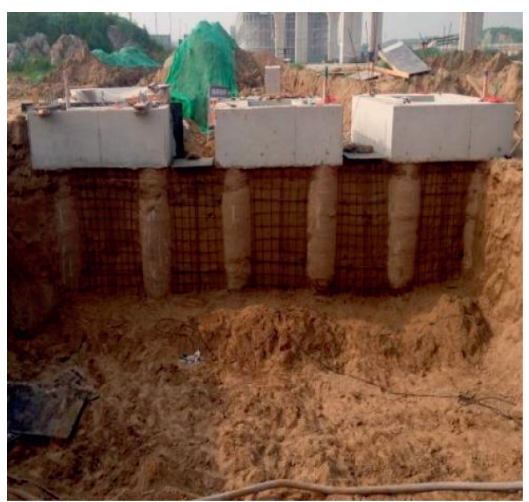

(b)

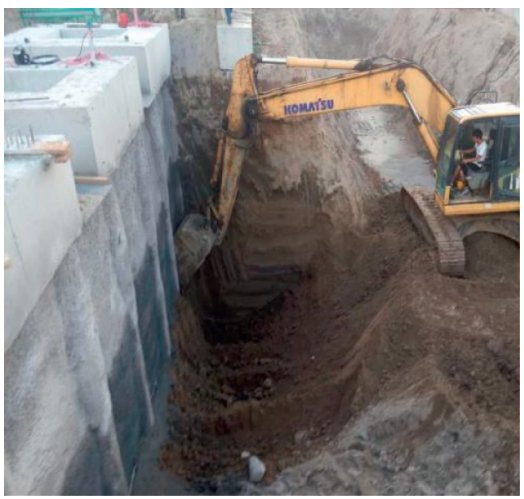

(e)

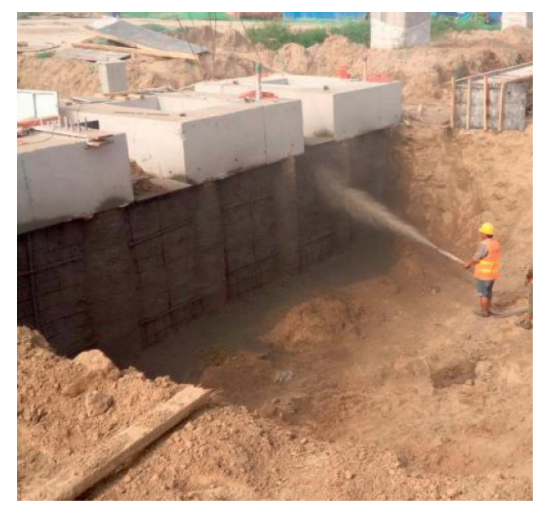

(c)

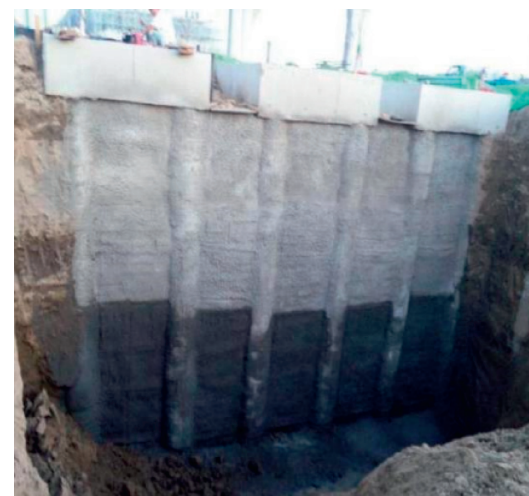

(f)

FIgURE 13: Excavation process of foundation pit. (a) Excavation of $2 \mathrm{~m}$. (b) Hanging net between piles. (c) Spraying concrete. (d) Excavation of $4 \mathrm{~m}$. (e) Excavation of $6 \mathrm{~m}$. (f) Excavation of $8 \mathrm{~m}$.

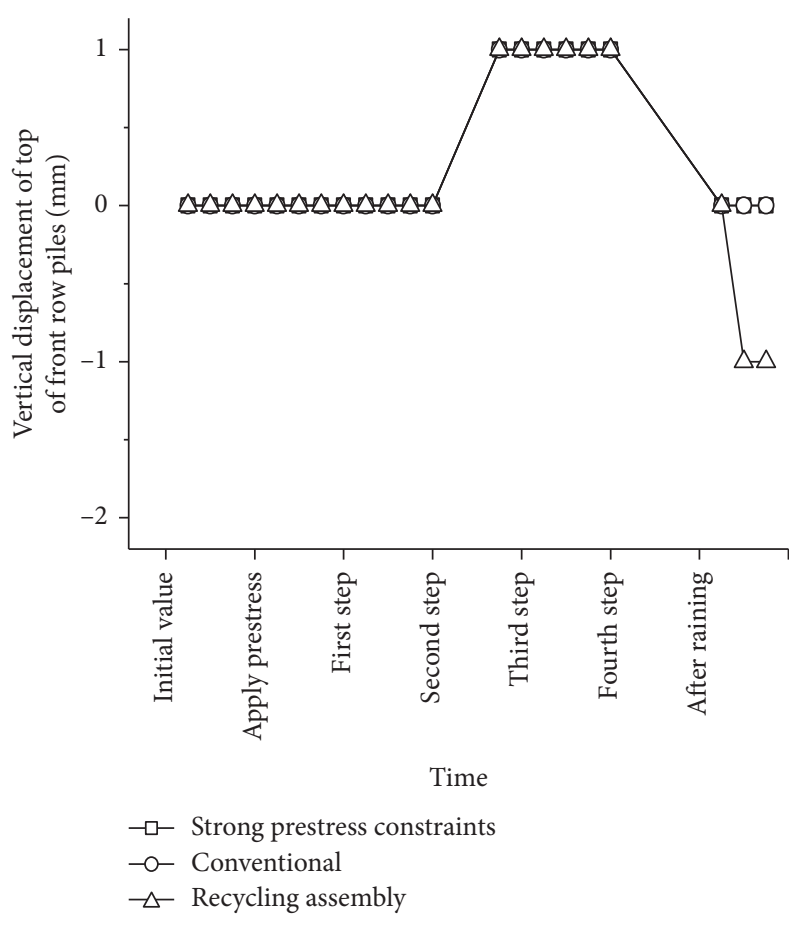

(a)

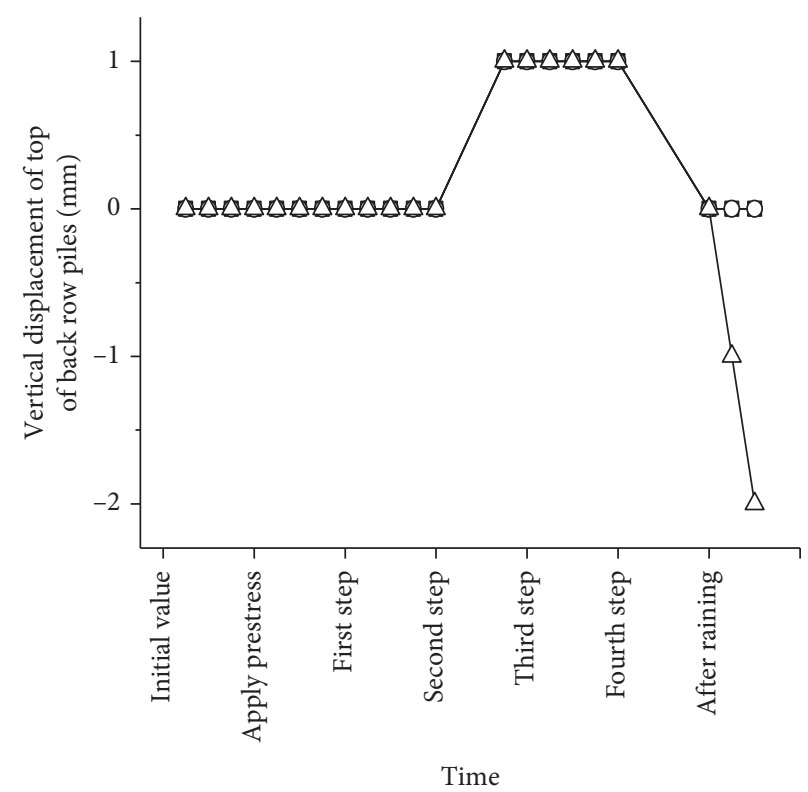

$-\square$ Strong prestress constraints
$-\_$Conventional
$\triangle$ Recycling assembly

(b)

FIgURE 14: Comparison of vertical displacement time history of pile top. (a) Front row pile. (b) Rear row pile. 


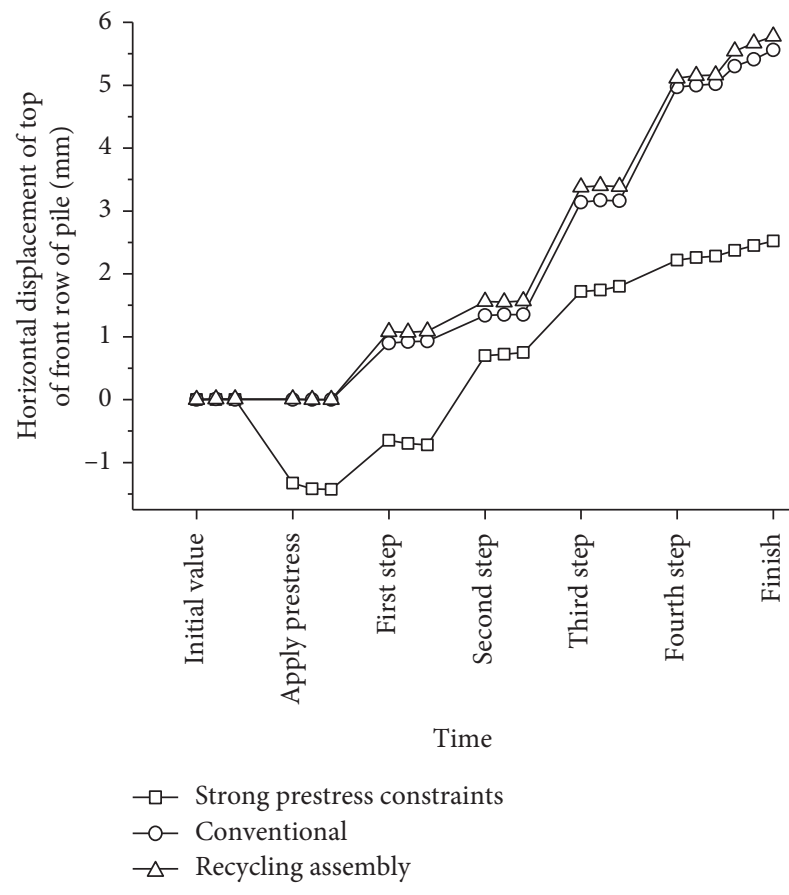

(a)

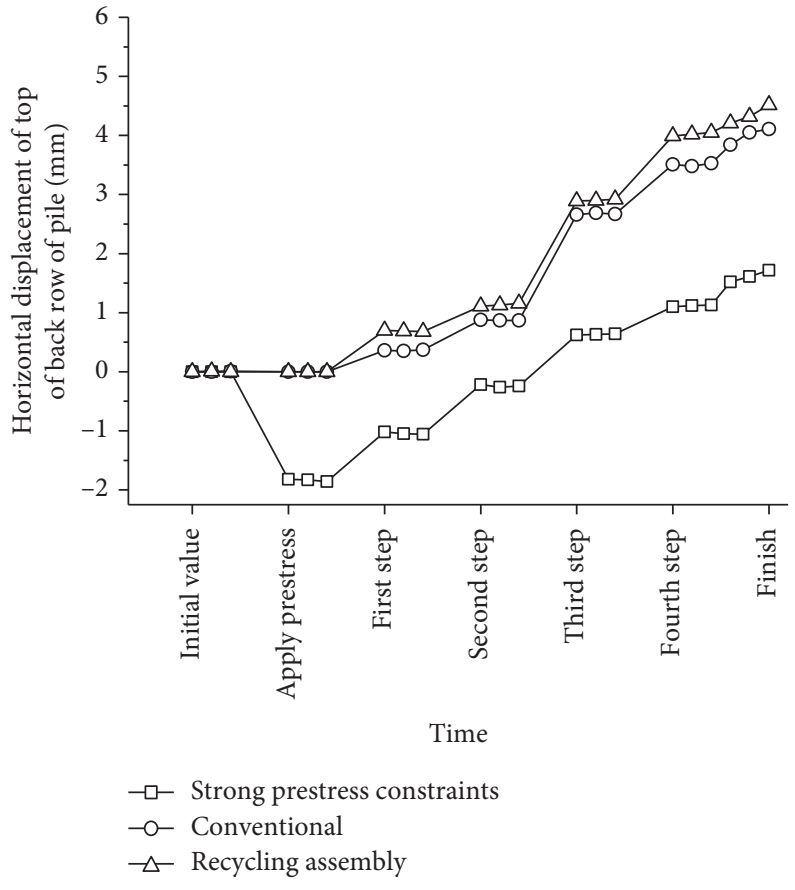

(b)

FIgURE 15: Comparison of horizontal displacement time history of pile top. (a) Front row pile. (b) Rear row pile.

5.2. Horizontal Displacement Analysis of Pile. It can be seen from Figure 16 that as the depth of pit excavation increases, the horizontal displacement of the pile gradually increases. In the first and second excavations, the maximum displacement is at the top of the pile. During the third or fourth excavations, the maximum displacement gradually moves downward, about 2-3 m below the top of the pile. It shows that with the increase of excavation depth of the foundation pit, the crown beam of the pile gradually exerts a restraining effect.

The front row pile of the prestressed strong-constrained pile appears as negative values in the early stage of monitoring, where the maximum displacement reaches $-1.82 \mathrm{~mm}$. The prestressed strong-constrained front row piles showed a negative value in the initial period of monitoring, and the maximum displacement reached $-1.82 \mathrm{~mm}$. That is to say, displacement of the pile top produces a deviation from the side of the foundation pit relative to the initial value, and then, as the excavation depth increases, the displacement gradually changes from a negative value to a positive value and increases continuously. This phenomenon indicates that the prestressed anchor cables of the prestressed and strongly constrained rear row piles exert a certain anchorage effect on the front row piles. The tension is transmitted to the front row pile top through the coupling beam. Therefore, the displacement change process of the front row pile top gradually converts from a negative value to a positive value, and the final displacement is smaller.

After the monitoring was complete, the horizontal displacement of the pile body was as shown in Figure 17. The overall variation trend of the three pile types was basically the same, and the curve was roughly a "right convex" type distribution. The horizontal displacement of the pile head of the recycling assembled pile is basically the same as that of the conventional pile, and their maximum displacements were $6.22 \mathrm{~mm}$ and $6.41 \mathrm{~mm}$. The horizontal displacement of the prestressed strong-constrained front piles is less than the former two, and its maximum displacement is $3.18 \mathrm{~mm}$. The results show that the prestressed strong-constrained supporting structure plays a significant role in controlling the maximum horizontal displacement of the front row piles. The horizontal displacement control effect of the front row piles of the recycling assembled supporting structure is almost the same as that of conventional piles.

\subsection{Deformation Analysis of Pile}

5.3.1. Strain of the Pile. The variation of strain at the end of the excavation and at the end of monitoring is shown in Figure 18. It is shown that the strain of the front row pile at the end of monitoring is larger than that at the end of excavation for the three types of piles, but the increase is minimal. It indicates that the strain has been basically completed during the excavation.

The strain distributions of the three types of piles in the front row are basically the same, and the effect of pulling and pressing on the front and rear sides of the pile is obvious. The maximum strain is in the middle of the pile, which is about $6 \mathrm{~m}$ below the pile top. It shows that the binding effect of the crown beam and soil is obvious. The front row pile above the excavation face is subjected to tensile stress before the pile and compressive stress behind the pile, resulting in tensile 


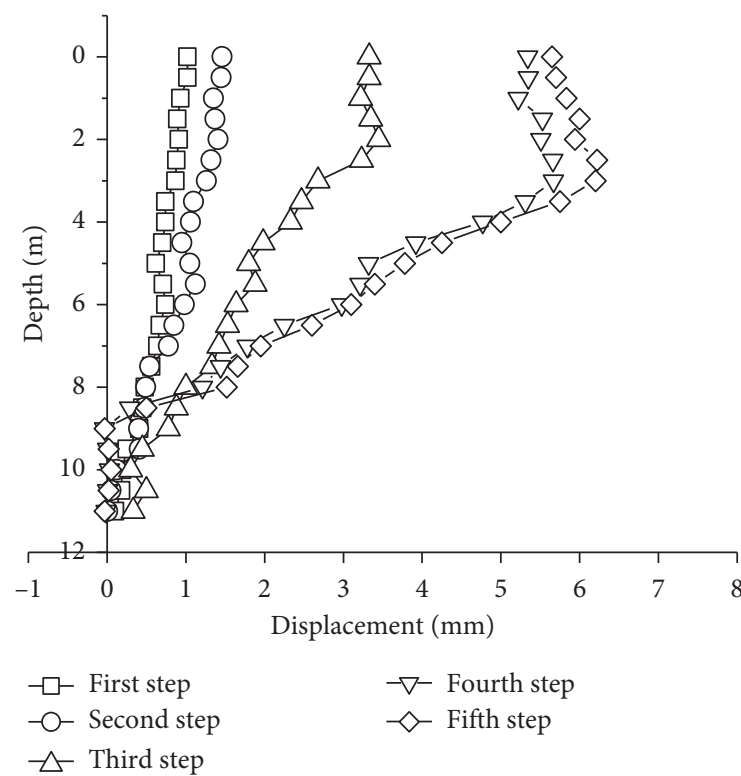

(a)

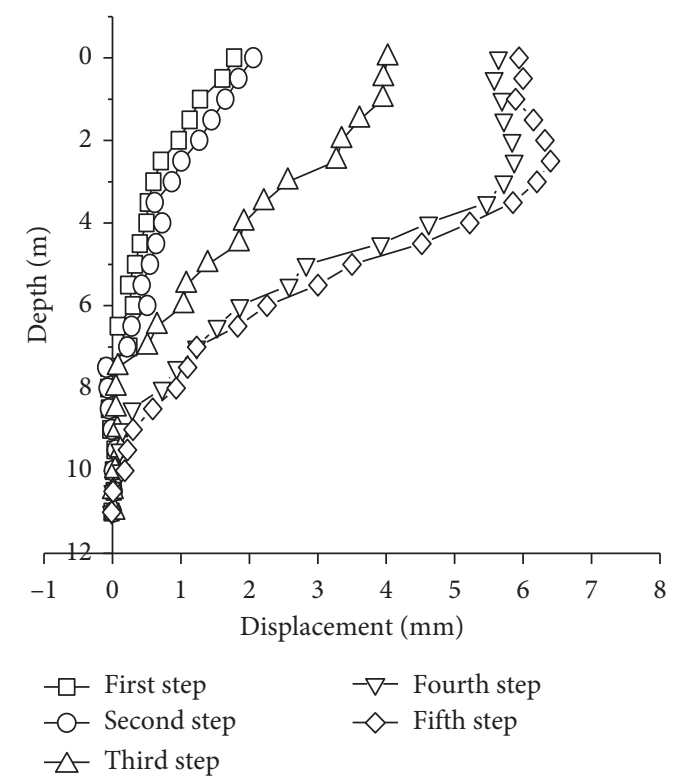

(b)

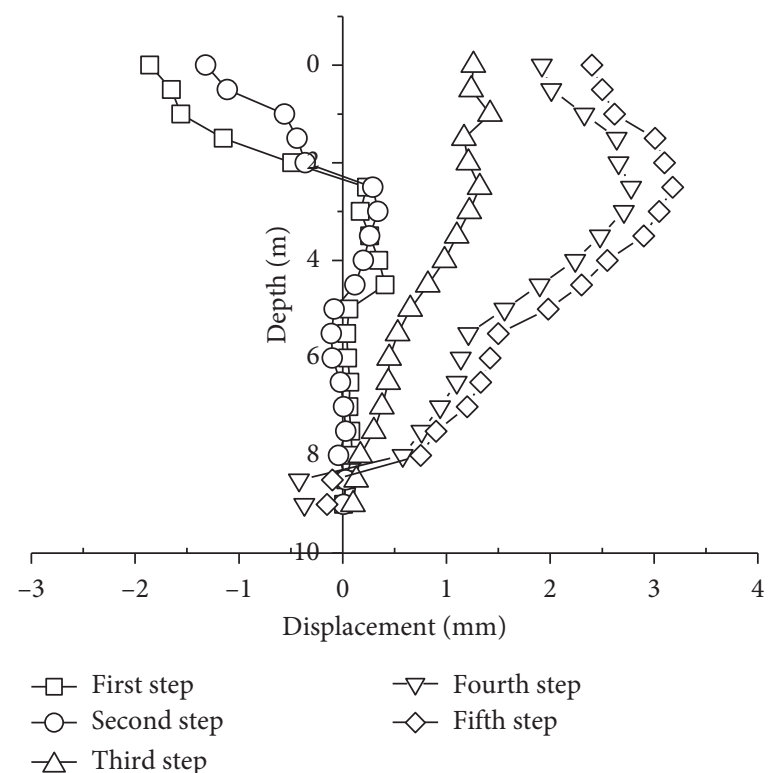

(c)

Figure 16: Horizontal displacement of front row piles. (a) Conventional front row pile. (b) Recycling assembled front row pile. (c) Prestressed strong-constrained front row pile.

deformation and compressive deformation; however, the tension and compression below the excavation face are the opposite. Due to the prestressing of the strong-constrained rear row pile anchors, the strain of the prestressed strongconstrained front row piles is less than that of the other two types of piles, especially at the $0-3 \mathrm{~m}$ position of the upper part of the pile where the effect is more pronounced.

5.3.2. Bending Moment of the Pile. It can be seen from Figure 19 that after the monitoring is complete, the bending moments of the three types of piles are basically in the same direction, with positive bending above the excavation surface and negative bending below the excavation surface. The three types of piles all have the largest bending moment at $6 \mathrm{~m}$, which shows that the crown beam and the bottom of the pile have certain restrictions on the pile body. Among them, the bending moments of the conventional type and the recycling assembled type are basically the same, and the maximum values are $70 \mathrm{kN} \cdot \mathrm{m}$ and $78 \mathrm{kN} \cdot \mathrm{m}$, respectively. The prestressed strong-constrained type generated less than the first two, with a maximum value of $42 \mathrm{kN} \cdot \mathrm{m}$, indicating that the prestressed anchor cable with prestressed strong-constrained type rear row has a certain restraining effect on the front row of piles. 


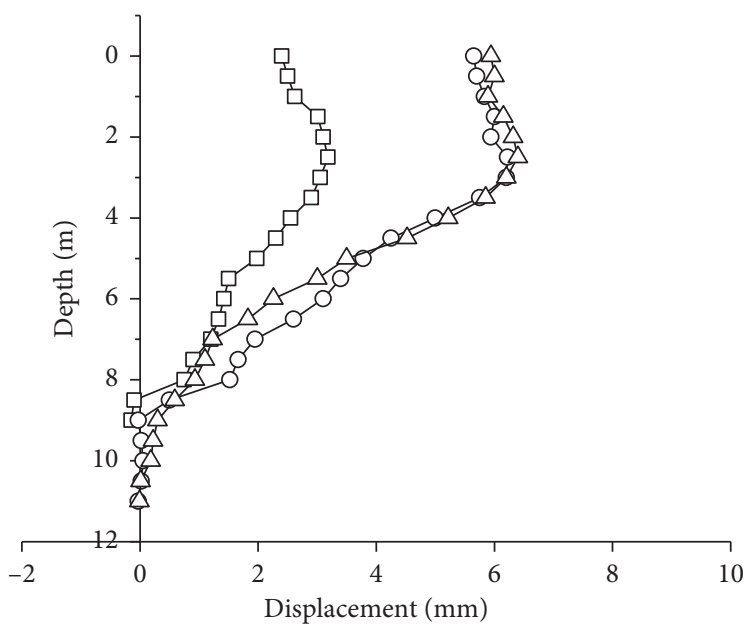

$$
\begin{aligned}
& -\square \text { Strong prestress constraints } \\
& -\bigcirc-\text { Conventional } \\
& -\square \text { Recycling assembly }
\end{aligned}
$$

FIGURE 17: The comparison of horizontal displacement for three front row piles.

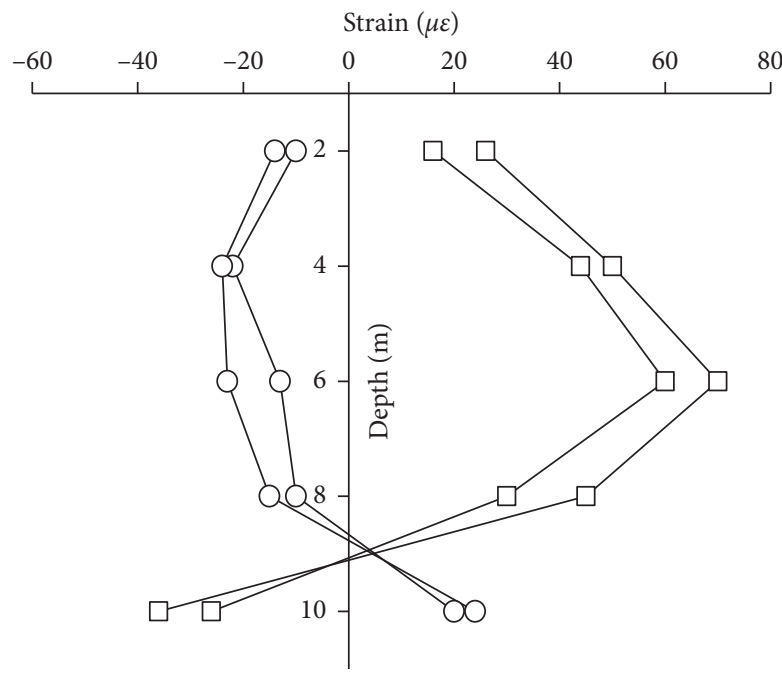

$\neg-$ Strain before the front row pile of conventional $-0-$ Strain after the front row pile of conventional

(a)

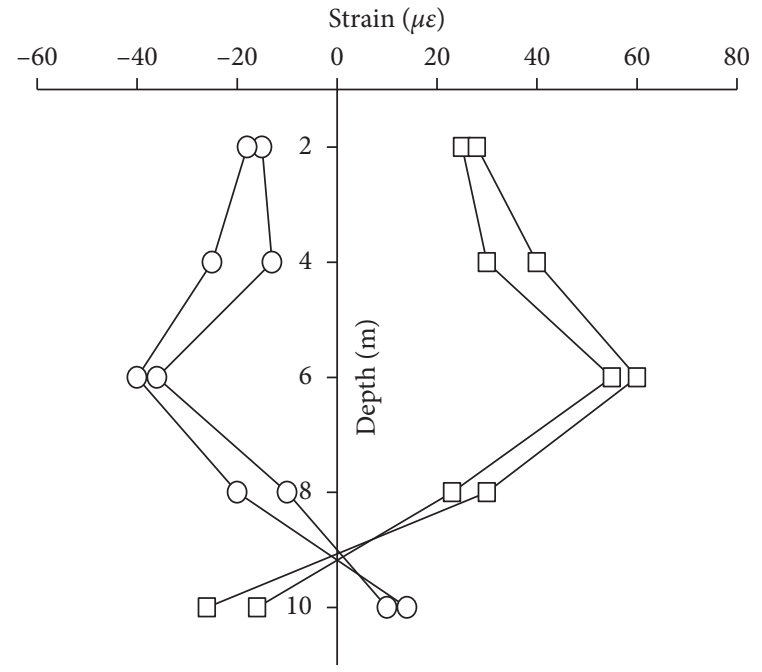

$\neg \square$ Front strain of prefabricated piles -O- Poststrain of prefabricated piles

(b)

FIgURE 18: Continued. 


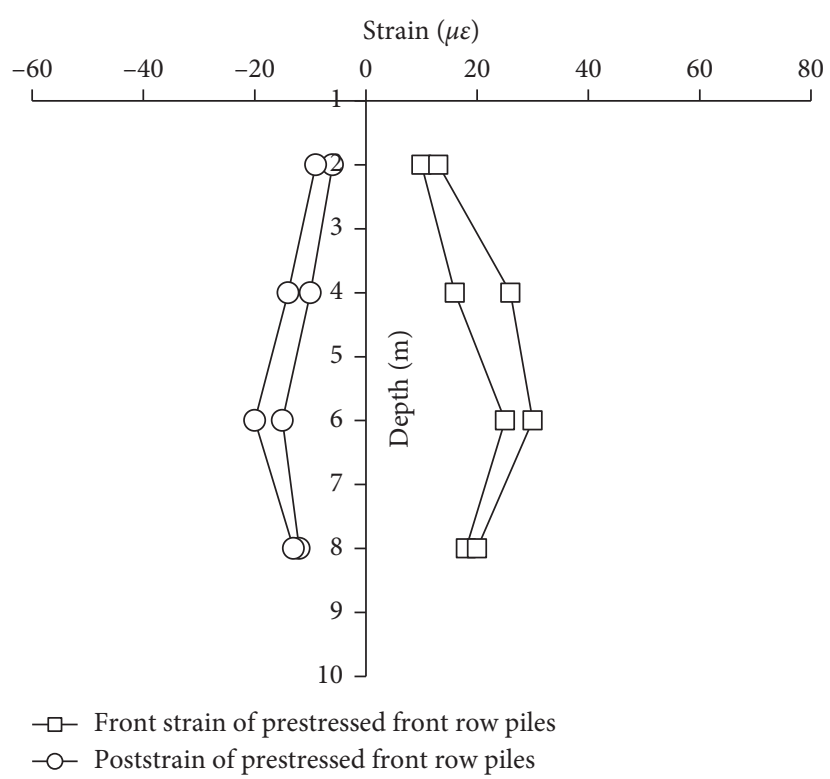

(c)

Figure 18: Variation of strain for front row piles. (a) Conventional pile. (b) Recycling assembled pile. (c) Prestressed strong-constrained pile.

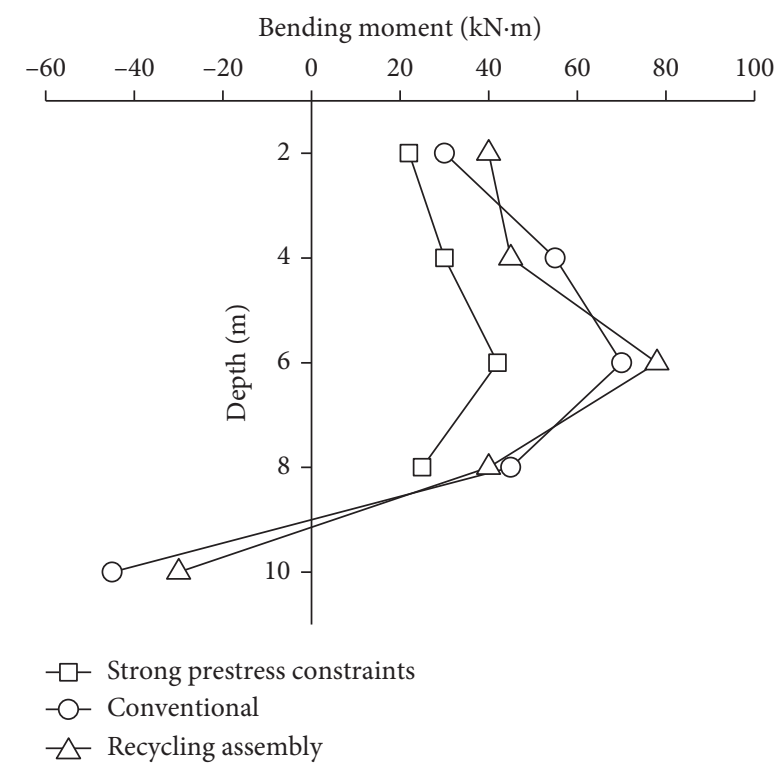

FIgURE 19: Comparison curve of bending moment.

In order to compare the deformation of the prestressed strong-constrained and conventional rear piles, strain gauges were laid at the same location of the two piles, $2 \mathrm{~m}$ below the top of the piles, away from the foundation pit, and the results were compared. According to the results presented in Figure 20, the conventional rear row pile has no prestressed anchor cable and the strain of the rear row pile shows an increase along with the excavation strain of the foundation pit, indicating that the conventional rear row pile is gradually subjected to tensile stress, and the main tensile strain occurs. This phenomenon is also consistent with the conclusion of the physical simulation test.

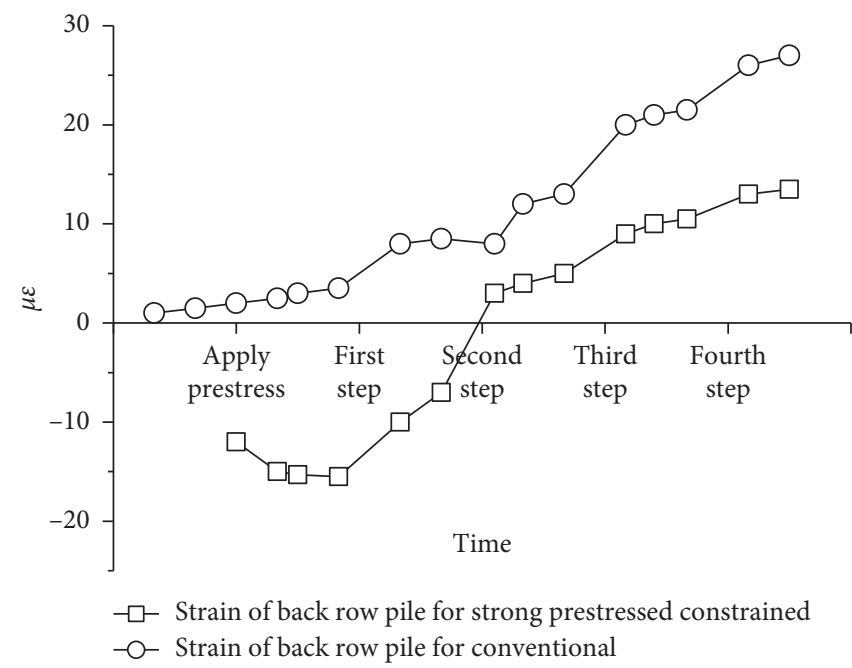

Figure 20: Comparison of strain at $2 \mathrm{~m}$ below the back row pile top.

Before excavation of the foundation pits, initial strain values were collected, and prestressing was then applied to the prestressed strong-constrained rear row pile anchors. Before the first excavation, due to the effect of prestressing, the strain value continues to decrease, indicating that the rear row piles have increased pressure and that the transmission of prestress has a certain time effect; the stress gradually is balanced thereafter. After the first excavation, due to the earth pressure generated by soil unloading, the strain value gradually increases, that is, the prestressed strong-constrained rear row piles change from compression to tension. After each excavation of the foundation pit, the strain value has a certain abrupt change, and the strain value increases gradually, which means that each excavation 
unloading of the soil exerts a significant tensile stress on the rear pile body. The ultimate strain value of the prestressed strong-constrained rear row pile is $13.5 \mu \varepsilon$ and the ultimate strain value of the conventional rear row pile is $27.2 \mu \varepsilon$, which indicate that the prestressed strong-constrained pile has a better restraining effect than the conventional one on the rear piles.

\section{Conclusions}

(1) The horizontal displacement of piles in the prestressed strong-constrained double-row piles and recycling assembled double-row piles supporting structures is basically the same as that of the conventional ones. After the foundation pit excavation is completed, the maximum horizontal displacement point appears in the upper part of the pile about 2$3 \mathrm{~m}$. The displacement of the prestressed strongconstrained type in each step of excavation is smaller than that of the conventional and recycling assembled types, and the overall horizontal displacement change trend between the conventional and recycling assembled types is basically the same.

(2) For the three types of supporting structure, the horizontal displacement of the front pile top is larger than the rear row pile, which explains that the influence of the active earth pressure on the front row pile is more obvious under the unloading of the foundation pit. The horizontal displacement values of the prestressed strong-constrained front and rear row piles are all smaller than the conventional and recycling assembled ones, indicating that the prestressed strong-constrained type has a better restraining effect on the front and rear rows of pile tops. Recycling assembled piles ensure that the displacement is similar to that of the conventional piles. Steel members are used to connect rear row piles and front row piles, which effectively reduces construction time and speeds up the construction process. After the foundation pits are backfilled, steel members can be recycled to save costs.

(3) Due to the existence of prestressed anchor cables in the rear row piles, the rear row piles of the prestressed strong-constrained supporting structure can provide better tensile performance. At the same time, the pulling anchor effect of prestressed anchor cable can restrain the displacement and deformation of prestressed strong-constrained front row piles, and the restraint effect on the top of the front row pile is especially obvious. It shows that the prestressed strong-constrained support structure has better deformation coordination ability.

\section{Data Availability}

The data used to support the findings of this study are included within the article.

\section{Conflicts of Interest}

The authors declare that there are no conflicts of interest.

\section{Acknowledgments}

The research was supported by the Fundamental Scientific Research Business Expenses of Provincial Universities in Hebei Province (JQN2020027) and North China University of Science and Technology Doctoral Research Startup Fund (BS201813).

\section{References}

[1] Profession Standard of the People's Republic of China, Technical Specification for Retaining and Protection of Building Foundation Excavation JGJ120-2012, Profession Standard of the People's Republic of China, Taiwan, China, 2012.

[2] X. N. Gong, Handbook for Design and Construction of Deep Foundation Pit, China Architecture \& Building Press, Beijing, China, 1998.

[3] S. L. Xing, J. S. Ye, and X. L. Yao, "Construction of bridge pile foundation finite element model and its application," Feature Structure, vol. 27, pp. 77-80, 2010.

[4] Y. J. Shen, H. Y. Sun, Y. Q. Shang et al., "Optimization design of double row anti-slide pile piers connection," Chinese Journal of Rock Mechanics and Engineering, vol. 29, pp. 3034-3038, 2010.

[5] J. F. Huang, C. G. Jiang, and S. L. Xing, "Study on finite element model of bridge pile foundation," Road Traffic Technology, vol. 7, pp. 161-163, 2011.

[6] G. Z. Qu and X. Q. Ye, "A new calculation method for the combined action of pile foundation and superstructure," Hubei Water Conservancy and Electricity Generation, vol. 3, pp. 16-18, 2001.

[7] Y. H. He, B. Yang, B. S. Jin et al., "Research and test of double row slope protection pile," Journal of Building Structure, vol. 2, pp. 58-66, 1996.

[8] Q. K. Nie, J. N. Hu, G. Wu et al., "Deformation and earth pressure of a double-row piles retaining structure for deep excavation," Rock and Soil Mechanics, vol. 155, no. 11, pp. 3089-3094, 2008.

[9] G. Zheng, X. Li, C. Liu et al., "Analysis of double-row piles in consideration of the pile-soil interaction," Journal of Building Structure, vol. 1, pp. 99-106, 2001.

[10] Y. Wang and B. Zhao, "Multilayer soil arching effect calculation and soil pressure analysis in double-row anti-sliding piles," Journal of Beijing University of Technology, vol. 8, pp. 1193-1199, 2008.

[11] Y. J. Zhou, A. J. Yao, X. Zheng et al., "Correction of earth pressure and analysis of deformation for double-row piles in foundation excavation in Changchun of China," Advanced in Materials Science and Engineering, vol. 2016, Article ID 9818160, 10 pages, 2016.

[12] C. Zhu, K. Zhang, H. Cai et al., "Combined application of optical fibers and CRLD bolts to monitor deformation of a pitin-pit foundation," Advances in Civil Engineering, vol. 2019, Article ID 2572034, 16 pages, 2019.

[13] C. Zhu, Z. Yan, Y. Lin, F. Xiong, and Z. Tao, "Design and application of a monitoring system for a deep railway foundation pit project," IEEE Access, vol. 7, Article ID 107591, 2019. 
[14] Q. Wang, H. Gao, B. Jiang, S. Li, M. He, and Q. Qin, "In-situ test and bolt-grouting design evaluation method of underground engineering based on digital drilling," International Journal of Rock Mechanics and Mining Sciences, vol. 138, Article ID 104575, 2021.

[15] N. Bella, I. Bella, and A. Asroun, "The application of equivalent age concept to sand concrete compared to ordinary concrete," Advanced in Civil Engineering, vol. 2016, Article ID 8940831, 7 pages, 2016.

[16] P. Colajanni, M. Papia, and N. Spinella, "Stress-strain law for confined concrete with hardening or softening behavior," Advanced in Civil Engineering, vol. 2013, Article ID 804904, 11 pages, 2013.

[17] Q. Wang, M. C. He, and S. C. Li, "Comparative study of model tests on automatically formed roadway and gob-side entry driving in deep coal mines," International Journal of Mining Science and Technology, 2021.

[18] Q. Wang, Y. Wang, and M. C. He, "Experimental research and application of automatically formed roadway without advance tunneling," Tunnelling and Underground Space Technology, vol. 114, Article ID 103999, 2021.

[19] A. Li, F. Dai, Y. Liu, H. Du, and R. Jiang, "Dynamic stability evaluation of underground cavern sidewalls against flexural toppling considering excavation-induced damage," Tunnelling and Underground Space Technology, vol. 112, Article ID 103903, 2021.

[20] X. J. Yang, J. M. Wang, C. Zhu, M. C. He, and Y. Gao, "Effect of wetting and drying cycles on microstructure of rock based on SEM," Environmental Earth Science, vol. 78, no. 6, p. 183, 2018.

[21] L. Ban, C. Zhu, C. Qi, and Z. Tao, "New roughness parameters for 3D roughness of rock joints," Bulletin of Engineering Geology and the Environment, vol. 78, no. 6, pp. 4505-4517, 2019.

[22] Q.-X. Meng, W.-Y. Xu, H.-L. Wang, X.-Y. Zhuang, W.-C. Xie, and T. Rabczuk, "DigiSim-an open source software package for heterogeneous material modeling based on digital image processing," Advances in Engineering Software, vol. 148, Article ID 102836, 2020.

[23] C. Zhu, M.-c. He, M. Karakus, X.-h. Zhang, and Z. Guo, "The collision experiment between rolling stones of different shapes and protective cushion in open-pit mines," Journal of Mountain Science, vol. 18, no. 5, pp. 1391-1403, 2021.

[24] Q. Yin, J. Y. Wu, C. Zhu, M. C. He, and Q. X. Meng, "Shear mechanical responses of sandstone exposed to high temperature under constant normal stiffness boundary conditions," Geomechanics and Geophysics for Geo-Energy and GeoResources, vol. 7, p. 35, 2021.

[25] Q. Wang, Z. Jiang, B. Jiang, H. Gao, Y. Huang, and P. Zhang, "Research on an automatic roadway formation method in deep mining areas by roof cutting with high-strength boltgrouting," International Journal of Rock Mechanics and Mining Sciences, vol. 128, Article ID 104264, 2020. 